\title{
Melasma, Novel Treatment Modalities
}

\section{Marwa Abdallah*}

Departmant of Dermatology and Venereology, Ain Shams University, Cairo, Egypt

${ }^{*}$ Corresponding author: Marwa Abdallah, Dermatology and Venereology Department 2 El-Fayoum Str, Korba, Heliopolis, Cairo, 11571, Egypt, Tel: +201001166299; Email: marwa_abdallah@hotmail.com

Rec date: Jul 08, 2014; Acc date: Aug 04, 2014; Pub date: Aug 07, 2014

Copyright: (C) 2014 Abdallah M. This is an open-access article distributed under the terms of the Creative Commons Attribution License, which permits unrestricted use, distribution, and reproduction in any medium, provided the original author and source are credited.

\begin{abstract}
Treatment of melasma remains challenging due to frequent relapses and the occurrence of post-inflammatory hyperpigmentation $(\mathrm{PIH})$ following many interventions. Treatment goals are inhibition of melanin synthesis and transfer by sunscreens, sun avoidance and the use of bleaching agents on one hand and removal of already present pigment by peeling, lasers and light on the other hand. Triple combination creams (TCC) (also known as Kligman's formula utilizing hydroquinone and modifications of Kligman's formula) remain the mainstay of treatment. Newer bleaching agents derived from plants and synthetic compounds have been introduced and many of them are promising safe substitutes for hydroquinone.
\end{abstract}

Peeling agents especially superficial and medium depth peels are effective treatment modalities for melasma. Newer peeling agents are less irritating and may thus lead to fewer side effects.

Q-switched lasers, which target melanin, have led to PIH until the innovation of "laser toning" and fractional Qswitched ruby, which have better outcomes. Fractional non-ablative and ablative lasers are useful at lower fluencies. Pulsed dye laser, which targets the vascular component in melasma, is promising with less melasma rebound.

Combinations of the above-mentioned modalities usually have a better treatment outcome than either alone. This review will focus on the more recently introduced therapies.

Keywords: Melasma; Bleaching; Peeling; Laser; Combination therapy

\section{Introduction}

Melasma is a common, acquired facial skin disorder, mostly involving sun-exposed areas like cheeks, forehead and upper lip. It is clinically divided according to its distribution into centrofacial, malar and mandibular patterns [1]

Histopathologically, melasma is associated with epidermal hyperpigmentation due to increased melanin formation and deposition rather than increased melanocyte numbers, weak basement membrane, elastosis, vascular proliferation with mild lymphohistiocytic infiltrates increased numbers of mast cells and dermal melanophages [2,3].

The pathogenesis of melasma is complex. Increasing evidences show that melanocytes are not the only cells involved, and that other players like keratinocytes and fibroblasts probably have a key role in the development and the relapses of melasma [4]. Ultraviolet (UV) light from sun exposure has a major role in induction and relapse of melasma. Pregnancy, oral contraceptive pills, family history and dark skin types remain among the major predisposing factors [5]. Interestingly, visible light, especially that in the blue-light range, can increase skin pigmentation adding to the burden of melasma relapse $[6,7]$.

Melasma is usually diagnosed clinically. Wood's light or, more recently, confocal laser microscopy help in localizing melanin level [8].
For evaluating the severity and degree of melasma, several scoring systems and tools have been proposed. The Melasma Area and Severity Index (MASI) is the most popular scoring system [9]. To calculate the MASI score, the sum of the severity rating for darkness (D) and homogeneity $(\mathrm{H})$ is multiplied by the numerical value of the areas involved (A) and by the various percentages of the four facial areas. These values are added to obtain the MASI score. Melasma Severity Scale (MSS) is a simpler way to grade melasma [10]. Colorimetry quantifies the melanin that is present in melasma lesions and the changes associated with improvement from the treatment using the $\mathrm{L}^{\star} \mathrm{a}^{\star} \mathrm{b}^{\star}$ color system, as determined by the Commission International de I'Eclairage. There are also the mexameter and the dermaspectrometer that can quantify melanin using melanin index [11]. Patient's subjective evaluation of improvement after treatment is graded into mild, less than $25 \%$; moderate, 25 to $<50 \%$; good, 50 to $<75 \%$; excellent, $>75 \%$, [12].

Due to the complex pathogenetic nature of melasma, treatment is challenging and relapses are the hallmark of the disease. Herein we will present the current therapies available for melasma with focus on newer treatment modalities. The main goal of therapeutic modalities is either suppression of melanogenesis and melanin transfer from the active melanocytes or removal of already present pigment in epidermis and dermis. 


\section{Treatment of Melasma}

\section{Suppression of melanogenesis}

Sunscreens: Strict avoidance of sunlight is mandatory. The use of tinted, mineral sunscreens is more beneficial than non-tinted, since they protect not only against ultraviolet but also against visible light [4]. In a recently published study, patients with melasma applying iron oxide-containing sunscreens in the morning and hydroquinone $4 \%$ in the evening obtained significantly better bleaching compared to those applying ordinary sunscreens and hydroquinone (Table 1) [13].

\begin{tabular}{|c|c|}
\hline Suppression of melanogenesis & $\begin{array}{l}\text { Removal of already present melanin } \\
\text { in the epidermis and dermis }\end{array}$ \\
\hline $\begin{array}{l}\text { Sunscreens } \\
\text { Tinted sunscreens (UV and visible } \\
\text { light) }\end{array}$ & $\begin{array}{l}\text { Peeling (superficial and medium } \\
\text { depth peels) } \\
\text { Trichloroacetic acid }(10-35 \%)\end{array}$ \\
\hline $\begin{array}{l}\text { Preparations that inhibit melanin } \\
\text { production } \\
\text { Hydroquinone } \\
\text { Arbutin } \\
\text { Ellagic acid } \\
\text { Rucinol } \\
\text { Azelaic acid }\end{array}$ & $\begin{array}{l}\text { Glycolic acid }(20-70 \%) \\
\text { Salicylic acid }(20-30 \%) \\
\text { Jessner's solution } \\
\text { Tretinoin peels } \\
\text { Newer peels } \\
\text { Phytic acid peels } \\
\text { Amino fruit peels }\end{array}$ \\
\hline $\begin{array}{l}\text { Licorice extract (glabridin and } \\
\text { liquitrin) } \\
\text { Kojic acid } \\
\text { Ascorbic acid } \\
\text { Retinoids } \\
\text { Newer preparations } \\
\text { Dioic Acid } \\
\text { N-Acetyl Glucosamine } \\
\text { Mulberry extract } \\
\text { Silymarin } \\
\text { Other botanicals } \\
\text { Resveratrol } \\
\text { Oligopeptides } \\
\text { Tranexamic Acid }\end{array}$ & $\begin{array}{l}\text { Lasers } \\
\text { Q-switched lasers } \\
\text { Ruby } \\
\text { Alexandrite } \\
\text { Nd-YAG } \\
\text { Ablative lasers } \\
\text { CO2 } \\
\text { Erbium } \\
\text { Fractional lasers } \\
\text { Fractional non-ablative } \\
\text { Fractional ablative } \\
\text { Fractional Q-switched ruby laser } \\
\text { Pulsed dye laser }\end{array}$ \\
\hline Metformin & Intense pulsed light \\
\hline $\begin{array}{l}\text { Preparations that inhibit melanin } \\
\text { transfer } \\
\text { Soy } \\
\text { Niacinamide }\end{array}$ & \\
\hline
\end{tabular}

Table 1: Treatment modalities for Melasma

\section{Preparations that inhibit melanin production and transfer}

Bleaching agents: Bleaching agents work mainly be inhibiting tyrosinase enzyme, which is the key enzyme in melanogenesis. The benchmark of bleaching agents is hydroquinone (HQ) $2-5 \%$. It is applied alone or better in combinations [14]. The classical combination, termed Kligman's formula consists of a bleaching agent (hydroquinone 5\%), an exfoliating agent (tretinoin 0.1\%) and topical steroid (dexamethasone). Topical steroids are not only antiinflammatory; they also inhibit melanocyte activity [15]. Other combinations and modifications on the original Kligman's formula have been developed over the years using different ingredients and/or different concentrations of ingredients. Kligman's formula or similar combinations will be referred to in this review as triple combination cream (TCC). In the United States, a TCC consisting of $4 \% \mathrm{HQ}, 0.01 \%$ fluocinoloneacetonide, and $0.05 \%$ tretinoin is currently the only HQcontaining drug that the Food and Drug Administration (FDA) has approved for the treatment of melasma [16].

The most significant adverse effects of HQ are irritation, confettilike depigmentation and ochronosis. Moreover, HQ is potentially cytotoxic, mutagenic and its metabolite may cause bone barrow toxicity in vitro and in laboratory animals $[14,17]$.

Due to the reported side effects of HQ, research has been in action to find other agents with hypo-pigmenting activity and yielded a vast amount of naturally occurring and synthetic compounds. A summary of such compounds with focus on the newer ones will be mentioned herein.

Arbutin is a naturally occurring derivative of HQ derived from the extract of the bearberry plant and has fewer adverse effects than HQ [18].

Ellagic acid is an antioxidant found in certain plants and fruits. It is also a substrate of tyrosinase, suggesting a possible inhibitory effect on the melanogenesis pathway $[18,19]$.

Rucinol is a resorcinol derivative and has been shown to inhibit tyrosinase and tyrosinase related protein-1 (TRP-1) [20].

Azelaic acid is a naturally occurring dicarboxylic acid synthesized by the yeast Malassezia. It weakly inhibits tyrosinase and has shown cytotoxic and anti-proliferative effects in abnormal melanocytes. Twenty percent azelaic acid cream applied twice daily may be more effective than hydroquinone $4 \%$ in reducing mild melisma [21].

Licorice extract; the main active ingredients in licorice roots are glabridin and liquitrin, both decrease pigmentation. Glabridin has additional anti-inflammatory activity [22,23].

Kojic acid (derivative of several fungal species) and ascorbic acid (vitamin C) inhibit melanogenesis by interacting with copper, which acts at the enzyme's active site [17]. Additionally, the antioxidant effects of ascorbic acid prevent the production of free radicals, which trigger melanogenesis and reduce oxidized melanin, changing the pigmentation from black to tan. Preparations containing 5 or $10 \%$ ascorbic acid alone are available, as well as combinations with other bleaching agents. When used alone, $5 \%$ ascorbic acid has a slow onset of action compared to $4 \% \mathrm{HQ}$ but with fewer adverse effects [24].

Kojic acid is used in $1-4 \%$ concentrations, usually in combination with other agents $[25,26]$. It is a known sensitizer and has been claimed to be mutagenic [17].

Retinoids, increase epidermal cell turnover, inhibit melanosome transfer, enhance the penetration of other topical agents, inhibit tyrosinase transcription and interrupt melanin synthesis. Topical tretinoin proved effective in melasma after its use for 40 weeks $[9,27]$. However, topical tretinoin commonly causes skin irritation and inflammation, which often results in worsening of melasma.

In the author's opinion, irritation caused by TCC containing HQand/or tretinoin could be minimized by using them day after day instead of their daily use. Patients could use moisturizer during the rest of the week. Additionally, the use of potent topical steroid initially (first 2 months) followed by a less potent one will not only decrease 
the irritation, but will also boost the response. We noticed that potent steroids have a stronger melanocyte inhibitory action compared to low potency steroids.

\section{Newer topical bleaching formulations}

Soy: Soy interferes with melanin transfer by inhibiting the proteinactivated receptor 2 (PAR-2) pathway. Two soybean-derived proteins, namely soybean trypsin inhibitor and the Bowman-Birk inhibitor, interfere with melanosome transfer by inhibiting thePAR-2 activation. In a blinded controlled 12-week study, authors evaluated the efficacy of a soy moisturizer containing soybean trypsin inhibitor and Bowman-Birk Inhibitor on 65 women with moderate facial photodamage. There was significant improvement in mottled pigmentation, blotchiness, dullness, fine lines, overall texture, and overall skin tone [28].

Dioic Acid: Octadecenedioic acid is a recently developed monounsaturated dicarboxylic acid that is structurally similar to azelaic acid. Its lightening effect occurs through the binding of peroxisome proliferator-activated receptor gamma (PPAR- $\gamma$ ), which results in reduced tyrosinase mRNA expression. One study compared twice-daily application of $1 \%$ dioic acid to $2 \%$ hydroquinone cream in 96 Mexican female subjects with melasma. Both agents demonstrated equal efficacy in reducing MASI scores over $40 \%$ after 12 weeks of treatment. Although adverse effects were similar between the 2, pruritus occurred more in hydroquinone group, whereas acne-form eruption was more prevalent in those using dioic acid. The latter was attributed to the oilier vehicle [29].

N-Acetyl Glucosamine: N-Acetyl glucosamine (NAG) is an aminomonosaccharide that inhibits enzymatic glycosylation, which is required to convert inactive protyrosinase to the active tyrosinase. It reduces melanin production and downregulates the gene expression of several intracellular cytoskeletal proteins that are involved in melanosome transport within the cell. In a double-blind, placebocontrolled split face study, 2\% NAG proved effective (30). Although formulating a topical agent has been difficult due to its instability, a recent study has demonstrated the potential for niosomes for improved NAG localization to the skin [30,31].

Mulberry extract: Several species of the Moraceae family exhibit antioxidant activity $[32,33]$. The focus here, though, will be on the skin-lightening activity of various parts of Morus (commonly known as mulberry) trees. Extracts of parts of white mulberry, paper mulberry and Chinese mulberry trees (leaves, stem, bark, fruits or roots) can actively inhibit tyrosinase enzyme that could even supersede the activity of hydroquinone and kojic acid [34,35].

A randomized, single-blind, placebo-controlled trial on the safety and efficacy of $75 \%$ mulberry (Morus alba) extract oil versus placebo as a topical treatment for melasma, showed that the mean MASI score significantly improved for the $75 \%$ mulberry extract oil group (mean difference, 1.19), compared to placebo (0.06). Mexameter and Melasma Quality of Life (MelasQOL) scores also showed statistically significant differences in the mulberry extract group [36].

Silymarin: Silymarin "Milk Thistle" is classically used as liver support in liver cirrhosis and chronic liver disease. Silymarin was also found to prevent photocarcinogenesis, and significantly prevents melanin production.

Altei et al. [37] published an experimental work on albino rabbits and melasma patients using silymarin (SM) cream. Twenty-four
Albino rabbits were randomly divided into 4 equal groups. [A] No treatment, $[\mathrm{B}]$ received placebo, $[\mathrm{C}]$ treated with SM cream $(0.1), \&$ [D] treated by SM (0.2), were applied topically before UV sun light exposure for 30 days, assessed clinically \&histopathologically. Ninetysix adults diagnosed with melasma were randomized to three equal groups to receive one of the tested drugs applied twice daily for 4 weeks, evaluated by the response; lesion size, MASI score, physician global assessment, and subjective assessment.

The clinical and histopathological observations were reduced significantly in SM groups. Topical SM showed tremendous improvement of melasma in a dose-dependent manner, and was effective in prevention of skin damage caused by UV sunlight. Authors concluded that it is a safe new candidate effective treatment for melasma.

Resveratrol: A potential topical agent to treat hyperpigmentation in skin of color is resveratrol. Resveratrol is a phytoalexin and nonflavonoidpolyphenolic antioxidant that is synthesized in plant cells subjected to stress. It can be found in grape skin extracts, red wine, purple grape juice, peanuts, mulberries, bilberries, blueberries, cranberries, and the Japanese knotweed. Its mechanism of action is unknown, and current data are conflicting. Animal studies have shown that resveratrol led to skin lightening in Bufomelanostictus due to distinct aggregation of pigment cells [38].

\section{Other botanicals as potential bleaching agents}

A number of flavonoids and polyphenols are under trial as future bleaching agents. They generally have anti-inflammatory activity and decrease reactive oxygen species. These are extracts of belides, green tea, coffee fruit, orchid, emblica, cabbage palm fern, ground ivy, French pine and German chamomile in addition to the abovementioned extracts of soybean, licorice, mulberry and silymarin [39].

Niacinamide: Studies on niacinamide have demonstrated a suppression of melanosome transfer suggesting the reduction of cutaneous pigmentation [40]. Topical niancinamide has other beneficial effects on the skin, including prevention of photoimmunosuppression and photocarcinogenesis, antiinflammatory effects in acne, rosacea, and psoriasis. It also increases biosynthesis of ceramides, as well as other stratum corneum lipids with enhanced epidermal permeability barrier function. Moreover, it has antiaging effects [41].

Twenty-seven melasma patients were randomized to receive $4 \%$ niacinamide cream on one side of the face, and $4 \%$ hydroquinone cream on the other side for eight weeks. Sunscreen was applied along the observation period. They were assessed by noninvasive techniques for the evaluation of skin color, as well as subjective scales and histological sections initially and after the treatment with niacinamide. All patients showed pigment improvement with both treatments. Colorimetric measures did not show statistical differences between both sides. However, good to excellent improvement was observed with niacinamide in $44 \%$ of patients, compared to $55 \%$ with hydroquinone. Niacinamide reduced the mast cell infiltrate and showed improvement of solar elastosis in melasma skin. Side effects were present in $18 \%$ with niacinamide versus $29 \%$ with hydroquinone [41].

Oligopeptides: Investigators have begun to explore the role of oligopeptides, as these molecules are easily degraded to naturally occurring, and thus non-toxic, amino acid constituents. The aim was to produce oligopeptides with high tyrosinase inhibiting activity, that 
Page 4 of 9

are neither cytotoxic nor mutagenic A number of peptide fragments have been shown to reduce pigment production [42-44].

In an attempt to find suitable oligopeptides, Ubeid et al. [45] studied a series of penta-, hexa- and octapeptides. Octapeptides P16-18 were found to be potent competitive tyrosinase inhibitors with minimal toxicity toward the major cell types of human skin.

Lumixyl $(0.01 \%)$ is a decapeptide, with a tyrosinase inhibitory activity. In a split-face, randomized, double-blind and placebocontrolled pilot study, the effect of twice-daily topical application of this oligopeptide $(0.01 \% \mathrm{w} / \mathrm{w})$ on moderate, recalcitrant melasma over a 16-week course was studied in 5 females (skin phototype IV) with recalcitrant melasma [46]. Treatment was well tolerated with no visible signs of irritation or allergy. All five participants demonstrated statistically significant improvement in the appearance of melasma and overall facial aesthetics with high patient satisfaction.

In two further studies, Lumixyl $(0.01 \%)$ was incorporated with antioxidant cleanser, $20 \%$ glycolic acid lotion and physical sunscreen in Caucasian [47] as well as Hispanic melasma patients [48]. The brightening system was well tolerated with no adverse events reported. Mean decreases of $36 \%, 46 \%, 54 \%$, and $60 \%$ in MASI scores were observed at weeks $4,8,12$, and 16 , respectively, which were further corroborated by standardized photography showing visible reduction in the appearance of melasma [48].

The tetrapeptide, Pro-Lys-Glu-Lys (PKEK) has proven skinlightening benefits on skin discoloration from melasma and PIH in subjects with skin types V-VI in South Africa, making it a good candidate for all racial groups [49].

Tranexamic Acid (TXA): Tranexamic acid (Cyklokapron ${ }^{\circledR}$ ) is an antifibrinolytic widely used to treat haemorrhage. TXA is a plasmin inhibitor and lysine analog. It inhibits UV-induced plasmin activity by preventing the binding of plasminogen to the lysine binding sites on keratinocytes, which decreases free arachidonic acid and its metabolites (prostaglandins) decreasing melanocyte tyrosinase activity. TXA decreases vessel numbers by antagonizing vascular endothelial growth factor (VEGF) and basic fibroblast growth factor (b FGF). Additionally it decreases mast cell numbers [50].

Trials using oral, topical and intralesional TXA in melasma and hyperpigmentation have been performed on TXA alone and in conjunction with other modalities [50-53].

Intradermal injection of TXA $(4 \mathrm{mg} / \mathrm{ml})$ at weekly intervals for 12 weeks yielded a significant decrease in MASI score from baseline to 8 and 12 weeks. The patients' self-assessment of melasma improvement showed that $9.4 \%$ had good (51-75\% lightening) and 76\% had fair improvement (26-50\% lightening). Side effects were minimal and all the patients tolerated the treatment well [51].

$\mathrm{Na}$ et al. (2012) [50] evaluated the efficacy of oral and topical TXA in melasma patients both clinically and histologically. Twenty-five melasma patients were instructed to take TXA tablets (2 tablets tds) and apply the cream twice daily for 8 weeks (each TXA tablet contained $125 \mathrm{mg}$ of TXA, $50 \mathrm{mg}$ of ascorbic acid, $40 \mathrm{mg}$ of L-cysteine, $4 \mathrm{mg}$ of calcium pantothenate and $1 \mathrm{mg}$ of pyridoxine chloride. The topical agent was $2 \%$ TXA and $2 \%$ niacinamide). Subjects were asked to use standard sunscreen on the whole face during the study period. TXA decreased epidermal pigmentation associated with melasma and also reversed melasma-related dermal changes, such asvessel number and increased numbers of mast cells. Combining other agents may contribute to the good outcome of treatment.
On the other hand, topical 5\% TXA cream failed to produce an effect on melasma in a split face, placebo controlled trial [52].

In combination with intense pulsed light (IPL) and low fluence Qswitched Nd:YAG laser, oral TXA improved the clinical efficacy in light- or laser-based melasma treatment especially during the period of relative high sun exposure without serious adverse effects [54].

In our experience, oral tranexamic acid $(250 \mathrm{mg})$ together with oral vitamin C $(500 \mathrm{mg})$ twice daily together with TCC were well tolerated and improved cases with melasma not responsive to topical treatment alone (unpublished data).

Metformin: Recently, the effects of metformin, a widely used drug in the treatment of type 2 diabetes, were investigated on melanogenesis both in vitro and in vivo (Lehraiki et al.). Metformin led to reduced melanin content in melanoma cells and in normal human melanocytes by decreasing cAMP accumulation and cAMP-responsive elementbinding protein phosphorylation. This inhibitory effect is correlated with decreased expression of master genes of melanogenesis, microphthalmia-associated transcription factor, tyrosinase, dopachrometautomerase, and tyrosinase-related protein 1. Interestingly, topical application of metformin induced tail whitening in mice and had as anti-melanogenic effect on reconstituted human epidermis and on human skin biopsies. These data emphasize the depigmenting effect of metformin and suggest a clinical strategy for using metformin in the topical treatment of hyperpigmentation disorders. Removal of already present melanin in the epidermis and dermis [55].

Chemical Peels: Chemical peeling or controlled chemical burns result in destruction of a portion of the epidermis and/or dermis followed by its exfoliation and subsequent resurfacing of epidermis along with remodeling of collagen, and elastic fibers during the repair process in the dermis. Superficial, medium depth and deep peels are available [56 ]. Since most melasma patients have a dark complexion and due to their melanocyte hypersensitivity, treatment is restricted to superficial and less to medium depth peels. Various chemical peeling agents like glycolic acid (20-70\%) [57], trichloroacetic acid (10-35\%) [56,58], salicylic acid (20-30\%) [59], Jessner's solution [60], tretinoin peels [12] and others have been proposed to treat melasma. They proved effective but with the risk of inflammation, PIH and or melasma rebound.

The value of priming the skin before treatment with bleaching creams, tretinoin (0.025-0.1\%), glycolic acid $(<15 \%)$ creams individually or as TCC and the use of TCC together with sunscreens during and after treatment sessions would add to the efficacy and decrease melasma relapse [61]. The more recently introduced phytic acid peels [62] and amino fruit peels [63] are better tolerated with less side effects than the classical peels [61].

Lasers and Light: Lasers proposed to treat melasma are the Qswitched, ablative, fractional (ablative and non-ablative) in addition to pulsed dye laser (PDL) and IPL.

Q-switched lasers (QS): Q-switched (QS) lasers target melanin as chromophore, according to their wavelengths, melanin in epidermis and dermis could be targeted. Preliminary studies onthe treatment of melasma with QS ruby $(694 \mathrm{~nm})$, QSalexandrite $(755 \mathrm{~nm})$ and QS Neodymium yttrium aluminumgarnet (Nd: YAG) $(1064 \mathrm{~nm})$ lasers resulted in worsening of melasma, $\mathrm{PIH}$ and sometimes, punctate depigmentation. These results were obtained on using QS lasers alone or in combination with ablative lasers [64-66]. 
Page 5 of 9

The recent introduction of low energy Q-switched lasers (LEQL) with large spot size and low fluencies do not disrupt the epidermis allowing for selective melanosome damage. LEQL are applied in few passes, weekly or biweekly for 5-10 sessions. The technique is also known as "laser toning" and has become popular in Asian countries [67].

Several studies reported good improvement of melasma [68-71], especially when patients were pretreated with TCC [72] or when combined with glycolic acid peels [73], IPL [74] or dermabrasion [75]. However, reports of patients developing spotty hypopigmentation, depigmentation, leukotrichia, rebound hyperpigmentation and recurrence of melasma are noteworthy especially with too frequent (weekly) and too many sessions (>6-10) [71,76,77].

Ablative lasers: Similarly, ablative non-fractionated carbon dioxide (CO2) and Erbium: yttrium, aluminum, garnet (Erbium: YAG) laser produced initial improvement of melasma, but this was followed by PIH within 3 to 6 weeks of laser treatment [78].

Fractional Lasers: Fractional technology is a technique, where microscopic thermal damage (fractional non-ablative, fractional photothermolysis, FP) or microscopic holes (fractional ablative) are created in the skin, such that neighboring keratinocytes rapidly correct the defects, allowing for less downtime and less complications compared to open wounds. Microscopic injury zones induced by fractional treatments allow transport of necrotic epidermal debris including melanin through a compromised dermoepidermal junction $[67,79]$.

Fractional Non-Ablative Laser: Controversy about the use of fractional erbium glass laser $(1550 \mathrm{~nm})$ in melasma has emerged from vast publications [80-85]. FP is a safe and effective treatment for refractory melasma, with long-term remission especially in fairskinned patients. Treatment of patients with skin types III+ should be with extreme caution, since darker skin types are more prone to develop PIH $[80,81]$. Given the high rate of PIH, FP should not be used at higher fluencies $(15 \mathrm{~mJ} /$ micro beam $)$ in the treatment of melasma[82]. The combination of FP with TCC is useful for patients with melasma resistant to topical therapy alone, but its long-term efficacy is limited [83].

On the other hand, other studies showed that FP does not provide a substantial benefit in treating melasma when compared with the sole application of a broad-spectrum sunscreen [84] and that its effect was comparable to TCA $15 \%$ peel treatments when used to treat moderateto-severe melasma, but neither treatment was long-lasting [85].

Fractional Ablative Lasers: In a case report, fractional $\mathrm{CO} 2$ was successful in treatment of refractory dermal melasma in a patient of skin type V [86].

Trelles et al. [79] compared the use of fractional CO2 alone, to TCC to both together in 3 groups of melasma patients. Although one month following treatment the satisfaction index was equal in the three groups, this index continued to decrease for the first two groups. At 6 and 12 months there was a statistically significant difference between the combined use of fractional CO2 laser and TCC, which showed the best results compared to the other two groups as regards MASI score and satisfaction index [79].

Since fractional Erbium: YAG has a better water absorption coefficient than $\mathrm{CO} 2$ and produces less thermal zone, it could be safer to use in treatment of melasma. On Comparing fractional Erbium:YAG to $15 \%$ TCA in twenty matched melasma patients, we found that both modalities yielded a significant improvement in MASI score from baseline with no rebound during the 4 months follow up period (accepted as poster presentation in international pigment cell congress, 2014).

Intense Pulsed Light (IPL): IPL operates in millisecond pulse durations; it is not possible to target dermal melanosomes, which have thermal relaxation times in the nanosecond range. IPL treatment produces transient improvement in epidermal, but not dermal, melasma. Treatment will often result in crusting of the pigmented lesions, and the resultant epidermal disruption may cause PIH $[87,88]$. However, combining IPL with TCC is a safe and effective treatment for refractory mixed and dermal melisma [89].

Similarly, combining IPL and low energy QS-Nd-YAG resulted in a $59.35 \%$ decrease in modified MASI score and no clinical aggravations were observed during the follow-up period [74].

\section{What is New in Laser therapy?}

\section{Fractional Thulium fiber 1927 nm}

Recently, Polder and Bruce [90] introduced the use of a novel 1927$\mathrm{nm}$ fractional thulium fiber laser to treat melasma. This wavelength has a higher absorption coefficient for water than the $1550 \mathrm{~nm}$ laser, hence targets the epidermal pigment with greater efficacy. Four sessions at 4 weeks interval led to statistically significant improvement in melasma without any PIH [90].

In a retrospective study, significant decrease in mean MASI score was reported at 4 weeks after laser treatment in 20 melasma patients. Patient assessment revealed that 12 out of 20 subjects had more than $50 \%$ clearance of their melasma. Recurrence was reported by 7 out of 15 patients who were successfully followed-up (mean 10.2 months). Two patients developed PIH that subsided with topical bleaching after 3 months [91].

Ho et al. [92] reported that fractional thulium fiber is safe and effective for Chinese melasma patients at 2 months follow up. Complications were edema, erythema and crusting in the early days and that one patient developed PIH.

\section{Fractional Q-switched ruby laser}

Fractional QS ruby laser was designed to treat melasma without getting the usual side effects from previous QS lasers. Low dose fractional QS ruby laser for 6 sessions led to a decrease in MASI and increase in lightness of the melasma lesions in Koreans. Results were maintained at 16 weeks after the last treatment [93]. In a retrospective study, Hilton et al. (2013) [94] reported PIH and melasma rebound in a significant number of Caucasian melasma cases 3 months after 1-3 sessions of fractional QS ruby laser. They recommended more sessions at lower doses and/or the use of TCC and sun avoidance for better treatment outcomes.

\section{Pulsed dye laser (PDL)}

Pulsed dye laser aims at targeting the vascular component in melasma. Vascular endothelial growth factor (VEGF) is highly expressed in melasma lesions and the melanocytes VEGF receptors 1 and 2, which are involved in the pigmentation process [95-98]. PDL may decrease melanocyte stimulation and more importantly, decrease subsequent relapses [99]. 
Page 6 of 9

A study was conducted on 17 patients with melasma who were treated with PDL and topical combination therapy in a split-face comparison. The combination treatment was compared with TCC alone. The laser treatment was started after 1 month of TCC applications. Bleaching cream (HQ 4\%, tretinoin $0.05 \%$ and flucinoloneacetonide $0.01 \%$ ) was applied to the whole face and PDL on one half of the face. PDL was applied in 2 doses; one targeting melanin and the other targeting vasculature. Three sessions were performed at 3 weekly intervals. The authors found that the side treated by PDL had a better outcome and showed decreased relapse after summer in skin photoypes SPT II, III. Patients with skin type IV experienced hyper pigmentation, which could be from dose targeting melanin [99].

\section{Combination therapy}

Combinations between different treatment modalities have been used. Different topical therapy combinations have been studied and combining topical, oral therapies with each other and/or with peeling and light therapies add to the efficacy of treatment especially in recalcitrant cases. Starting by TCC before other treatment modalities decrease the incidence of PIH and may decrease melasma relapse $[54,61,72,74,75,79,83,89,99]$.

\section{Maintenance}

After successful treatment of melasma, it is very important to maintain the results. This is achieved by continued strict sun avoidance, use of sunscreens ( $>50 \mathrm{SPF}$ ), especially tinted ones and the use of bleaching creams. To evaluate efficacy of maintenance therapy with TCC, a twice-weekly regimen of TCC versus a gradually decreasing frequency were evaluated. Both were effective in postponing relapse in more than $53 \%$ over 6 months. The twiceweekly regimen tended to show better effectiveness in postponing relapse in severe melisma [100].

\section{Conclusions}

"Once Melasma, Always Melasma" this quotation is still applicable for melasma patients, since they probably have specialized melanocytes with intrinsic sensitivity to different stimuli. Due to the extreme sensitivity of melanocytes in melisma patients, the main drawback of many treatment tools is post-inflammatory hyperpigmentation and melasma rebound especially if the topical treatment is irritant or if the tool is used aggressively (Table 2). Sun avoidance and the use of sunscreens are crucial. Many new therapies are upcoming. Maybe substances that work on melasma-associated vasculature have a more promising future with less relapses.

\begin{tabular}{|c|c|c|c|}
\hline Preparation & $\begin{array}{l}\text { Mechanism of } \\
\text { Action }\end{array}$ & Indications & Side Effects \\
\hline $\begin{array}{l}\text { Hydroquinone } \\
(2-5 \%)\end{array}$ & $\begin{array}{l}\text { Tyrosinase } \\
\text { inhibitor }\end{array}$ & $\begin{array}{l}\text { Alone or in } \\
\text { combination } \\
\text { (TCC). First step in } \\
\text { melasma } \\
\text { treatment, in } \\
\text { combination with } \\
\text { other } \\
\text { (priming, tools } \\
\text { maintenance) }\end{array}$ & $\begin{array}{l}\text { Irritation, confetti- } \\
\text { like } \\
\text { depigmentation, } \\
\text { ochronosis } \\
\text { Cytotoxic? } \\
\text { Mutagenic? }\end{array}$ \\
\hline Kojic acid & $\begin{array}{lr}\text { Interferes } & \text { with } \\
\text { copper } & \text { at } \\
\text { tyrosinase } & \text { active } \\
\text { site } & \end{array}$ & $\begin{array}{l}\text { Alone or in } \\
\text { combination with } \\
\text { other topical } \\
\text { therapies }\end{array}$ & $\begin{array}{l}\text { Contact sensitizer } \\
\text { mutagenic? }\end{array}$ \\
\hline
\end{tabular}

\begin{tabular}{|c|c|c|c|}
\hline $\begin{array}{l}\text { Azaleic acid } \\
20 \%\end{array}$ & $\begin{array}{l}\text { Tyrosinase } \\
\text { inhibitor (weak) }\end{array}$ & $\begin{array}{lrr}\text { Alone or } & \text { in } \\
\text { combination with } \\
\text { other r topical } \\
\text { therapies }\end{array}$ & $\begin{array}{l}\text { Irritation, initial } \\
\text { burning sensation. }\end{array}$ \\
\hline Retinoids & $\begin{array}{l}\text { Peeling, } \\
\text { tyrosinase } \\
\text { inhibitor, inhibits } \\
\text { melanosome } \\
\text { transfer }\end{array}$ & $\begin{array}{|lr|}\text { Usually } & \text { in } \\
\text { combination with } \\
\text { other } & \text { topical } \\
\text { therapies } & \end{array}$ & $\begin{array}{l}\text { Irritation and } \\
\text { inflammation, } \\
\text { which may result in } \\
\text { worsening of } \\
\text { melasma, slow } \\
\text { onset of action }\end{array}$ \\
\hline Dioic Acid & $\begin{array}{l}\text { Inhibits } \\
\text { melanosometranfe } \\
r\end{array}$ & $\begin{array}{l}\text { Still under trial as } \\
\text { alternative to older } \\
\text { preparations }\end{array}$ & $\begin{array}{l}\text { Pruritus, irritation } \\
\text { (mild) } \\
\text { Acne-form eruption } \\
\text { (oily vehicle) }\end{array}$ \\
\hline $\begin{array}{l}\text { Tranexamic } \\
\text { Acid }\end{array}$ & $\begin{array}{l}\text { TXA inhibits } \\
\text { binding of } \\
\text { plasminogen to } \\
\text { the lysine binding } \\
\text { sites } \\
\text { keratinocytes, on } \\
\text { which eventually } \\
\text { decreases } \\
\text { prostaglandins \& } \\
\text { melanocyte } \\
\text { tyrosinase activity. } \\
\text { TXA decreases } \\
\text { vessel numbers \& } \\
\text { mast cell numbers }\end{array}$ & $\begin{array}{lr}\text { Oral } & \text { and } \\
\text { intralesional } & \text { TXA } \\
\text { maybe } & \text { more } \\
\text { beneficial } & \text { than } \\
\text { topical TXA } & \\
& \\
& \\
& \\
\end{array}$ & $\begin{array}{l}\text { Oral TXA may lead } \\
\text { to } \quad \text { nausea, } \\
\text { vomiting, diarrhea, } \\
\text { or dizziness }\end{array}$ \\
\hline Chemical Peels & $\begin{array}{l}\text { Increase } \\
\text { epidermal } \\
\text { turnover, remove } \\
\text { already present } \\
\text { melanin }\end{array}$ & $\begin{array}{l}\text { Second line } \\
\text { treatment, alone or } \\
\text { better with TCC }\end{array}$ & $\begin{array}{l}\text { Inflammation, } \mathrm{PIH} \text {, } \\
\text { melasma rebound }\end{array}$ \\
\hline $\begin{array}{l}\text { Q-switched } \\
\text { lasers }\end{array}$ & $\begin{array}{l}\text { Disrupts } \\
\text { melanosomes }\end{array}$ & $\begin{array}{lr}\text { Could reach } \\
\text { dermal } & \text { melanin } \\
\text { removing } & \text { it } \\
\text { (depending } & \text { on } \\
\text { wavelength). } \\
\begin{array}{l}\text { Epidermal } \\
\text { dermal melasma }\end{array}\end{array}$ & $\begin{array}{l}\text { Worsening of } \\
\text { melasma, } \\
\text { punctate } \\
\text { depigmentation }\end{array}$ \\
\hline $\begin{array}{l}\text { Low energy Q- } \\
\text { switched lasers }\end{array}$ & $\begin{array}{l}\text { Disrupts } \\
\text { melanosomes }\end{array}$ & $\begin{array}{lr}\mathrm{Nd}: Y A G & \text { laser } \\
\text { reaches deep in } \\
\text { dermis removing } \\
\text { melanin from there }\end{array}$ & $\begin{array}{l}\text { Spotty } \\
\text { hypopigmentation, } \\
\text { depigmentation, } \\
\text { leukotrichia, } \\
\text { rebound } \\
\text { hyperpigmentation, } \\
\text { recurrence of } \\
\text { melasma }\end{array}$ \\
\hline $\begin{array}{l}\text { Fractional Q- } \\
\text { switched ruby } \\
\text { laser }\end{array}$ & $\begin{array}{l}\text { Disrupts } \\
\text { melanosomes. }\end{array}$ & $\begin{array}{l}\text { More superficial } \\
\text { than Nd:YAG }\end{array}$ & $\begin{array}{l}\mathrm{PIH}, \quad \text { melasma } \\
\text { rebound (less than } \\
\text { conventional QS) }\end{array}$ \\
\hline Ablative lasers & $\begin{array}{l}\text { Ablates skin, } \\
\text { removing with it } \\
\text { melanin particles }\end{array}$ & $\begin{array}{l}\text { Epidermal and } \\
\text { dermal melasma }\end{array}$ & $\begin{array}{l}\text { PIH (3 to } 6 \text { weeks } \\
\text { after } \\
\text { treatment) laser } \\
\text { especially with } \\
\text { deeper, aggressive } \\
\text { treatment }\end{array}$ \\
\hline $\begin{array}{l}\text { Fractional non- } \\
\text { ablative laser }\end{array}$ & $\begin{array}{l}\text { Creates } \\
\text { microthermal } \\
\text { zones through } \\
\text { which melanin can } \\
\text { be extruded }\end{array}$ & $\begin{array}{l}\text { Epidermal and } \\
\text { dermal melasma, } \\
\text { less downtime }\end{array}$ & $\begin{array}{l}\text { PIH (darker skin } \\
\text { types, higher } \\
\text { fluencies), } \\
\text { melasma rebound }\end{array}$ \\
\hline $\begin{array}{l}\text { Fractional } \\
\text { Thulium fiber } \\
1927 \mathrm{~nm}\end{array}$ & $\begin{array}{l}\text { Non-ablative laser } \\
\text { with higher water } \\
\text { absorption } \\
\text { coefficient }\end{array}$ & $\begin{array}{l}\text { Epidermal and } \\
\text { dermal melasma, } \\
\text { less downtime }\end{array}$ & $\begin{array}{l}\text { Edema, erythema } \\
\text { and crusting (early } \\
\text { days), } \\
\text { recurrence PIH }\end{array}$ \\
\hline
\end{tabular}




\begin{tabular}{|l|l|l|l|}
\hline & & & $\begin{array}{l}\text { melasma (less than } \\
\text { other lasers) }\end{array}$ \\
\hline $\begin{array}{l}\text { Fractional } \\
\text { Ablative Lasers }\end{array}$ & $\begin{array}{l}\text { Creates small } \\
\text { channels through } \\
\text { which melanin can } \\
\text { be extruded }\end{array}$ & $\begin{array}{l}\text { Epidermal and } \\
\text { dermal melasma, } \\
\text { less downtime }\end{array}$ & $\begin{array}{l}\text { PIH? Melasma } \\
\text { rebound? }\end{array}$ \\
\hline $\begin{array}{l}\text { Intense Pulsed } \\
\text { Light }\end{array}$ & $\begin{array}{l}\text { Probably targeting } \\
\text { vascular } \\
\text { component }\end{array}$ & $\begin{array}{l}\text { Crusting of the } \\
\text { pigmented lesions, } \\
\text { PIH }\end{array}$ \\
\hline $\begin{array}{l}\text { Pulsed dye } \\
\text { laser }\end{array}$ & $\begin{array}{l}\text { Vascular mode, } \\
\text { targets dermal } \\
\text { blood vessels } \\
\text { Pigment mode } \\
\text { targets melanin }\end{array}$ & $\begin{array}{l}\text { Decreases the } \\
\text { vascular } \\
\text { component of } \\
\text { melasma }\end{array}$ & $\begin{array}{l}\text { PIH (darker skin } \\
\text { types, maybe from } \\
\text { pigment mode?) }\end{array}$ \\
\hline
\end{tabular}

Table 2: Mechanism of action, indications and side effects of the most commonly used tools in melasma treatment $(\mathrm{PIH}=$ post inflammatory hyperpigmentation, $\mathrm{QS}=\mathrm{Q}$-switched laser, $\mathrm{TCC}=$ triple combination therapy, TXA=tranexamic acid)

\section{References}

1. Kang WH, Yoon KH, Lee ES, Kim J, Lee KB, et al. (2002) Melasma histopathological characteristics in 56 Korean patients. Br J Dermatol 146: 228-237.

2. Grimes PE, Yamada N, Bhawan J (2005) Light microscopic, immunohistochemical, and ultrastructural alterations in patients with melasma. Am J Dermatopathol 27: 96-101.

3. Torres-Álvarez B, Mesa-Garza IG, Castanedo-Cázares JP, FuentesAhumada C, Oros-Ovalle C, et al. (2011) Histochemical and immunohistochemical study in melasma: evidence of damage in the basal membrane. Am J Dermatopathol 33: 291-295.

4. Passeron T (2013) Melasma pathogenesis and influencing factors - an overview of the latest research. J Eur Acad Dermatol Venereol 27 Suppl 1: 5-6.

5. Ortonne JP, Arellano I, Berneburg M, Cestari T, Chan H, et al. (2009) A global survey of the role of ultraviolet radiation and hormonal influences in the development of melasma. J Eur Acad Dermatol Venereol 23: 1254-1262.

6. Mahmoud BH, Ruvolo E, Hexsel CL, Liu Y, Owen MR, et al. (2010) Impact of long-wavelength UVA and visible light on melanocompetent skin. J Invest Dermatol 130: 2092-2097.

7. Duteil L, Cardot-Leccia N, Queille-Roussel C, Maubert Y, Harmelin Y, et al. (2014) Differences in visible light-induced pigmentation according to wavelengths: a clinical and histological study in comparison with UVB exposure. Pigment Cell Melanoma Res 27: 822-826.

8. Kang HY, Bahadoran P, Suzuki I, Zugaj D, Khemis A, et al. (2010) In vivo reflectance confocal microscopy detects pigmentary changes in melasma at a cellular level resolution. Exp Dermatol 19: e228-233.

9. Kimbrough-Green CK, Griffiths CE, Finkel LJ, Hamilton TA, BulengoRansby SM, et al. (1994) Topical retinoic acid (tretinoin) for melasma in black patients. A vehicle-controlled clinical trial. Arch Dermatol 130: 727-733.

10. Taylor SC (2007) Objective and Subjective Measures of Melasma. Cosmet Dermatol 20: 93-95.

11. Clarys P, Alewaeters K, Lambrecht R, Barel AO (2000) Skin color measurements: comparison between three instruments: the Chromameter(R), the DermaSpectrometer(R) and the Mexameter(R). Skin Res Technol 6: 230-238.

12. Khunger N, Sarkar R, Jain RK (2004) Tretinoin peels versus glycolic acid peels in the treatment of Melasma in dark-skinned patients. Dermatol Surg 30: 756-760.
13. Castanedo-Cazares JP, Hernandez-Blanco D, Carlos-Ortega B, FuentesAhumada C, Torres-Álvarez B (2014) Near-visible light and UV photoprotection in the treatment of melasma: a double-blind randomized trial. Photodermatol Photoimmunol Photomed 30: 35-42.

14. Jutley GS, Rajaratnam R2, Halpern J3, Salim A4, Emmett C5 (2014) Systematic review of randomized controlled trials on interventions for melasma: an abridged Cochrane review. J Am Acad Dermatol 70: 369-373.

15. Kligman AM, Willis I (1975) A new formula for depigmenting human skin. Arch Dermatol 111: 40-48.

16. Grimes P, Kelly AP, Torok H, Willis I (2006) Community-based trial of a triple-combination agent for the treatment of facial melasma. Cutis 77: 177-184.

17. Draelos ZD (2007) Skin lightening preparations and the hydroquinone controversy. Dermatol Ther 20: 308-313.

18. Ertam I, Mutlu B, Unal I, Alper S, Kivçak B, et al. (2008) Efficiency of ellagic acid and arbutin in melasma: a randomized, prospective, openlabel study. J Dermatol 35: 570-574.

19. Muñoz-Muñoz JL, Garcia-Molina F, Garcia-Molina M, Tudela J, GarcíaCánovas F, et al. (2009) Ellagic acid: characterization as substrate of polyphenol oxidase. IUBMB Life 61: 171-177.

20. Khemis A, Kaiafa A, Queille-Roussel C, Duteil L, Ortonne JP (2007) Evaluation of efficacy and safety of rucinol serum in patients with melasma: a randomized controlled trial. Br J Dermatol 156: 997-1004.

21. Farshi S (2011) Comparative study of therapeutic effects of $20 \%$ azelaic acid and hydroquinone $4 \%$ cream in the treatment of melasma. J Cosmet Dermatol 10: 282-287.

22. Yokota T, Nishio H, Kubota Y, Mizoguchi M (1998) The inhibitory effect of glabridin from licorice extracts on melanogenesis and inflammation. Pigment Cell Res 11: 355-361.

23. Amer M, Metwalli M (2000) Topical liquiritin improves melasma. Int J Dermatol 39: 299-301.

24. Espinal-Perez LE, Moncada B, Castanedo-Cazares JP (2004) A doubleblind randomized trial of $5 \%$ ascorbic acid vs. $4 \%$ hydroquinone in melasma. Int J Dermatol 43: 604-607.

25. Lim JT (1999) Treatment of melasma using kojic acid in a gel containing hydroquinone and glycolic acid. Dermatol Surg 25: 282-284.

26. Vashi NA, Kundu RV (2013) Facial hyperpigmentation: causes and treatment. Br J Dermatol 169 Suppl 3: 41-56.

27. Griffiths CE, Finkel LJ, Ditre CM, Hamilton TA, Ellis CN, et al. (1993) Topical tretinoin (retinoic acid) improves melasma. A vehicle-controlled, clinical trial. Br J Dermatol 129: 415-421.

28. Wallo W, Nebus J, Leyden JJ (2007) Efficacy of a soy moisturizer in photoaging: a double-blind, vehicle-controlled, 12-week study. J Drugs Dermatol 6: 917-922.

29. Tirado-Sánchez A, Santamaría-Román A, Ponce-Olivera RM (2009) Efficacy of dioic acid compared with hydroquinone in the treatment of melasma. Int J Dermatol 48: 893-895.

30. Bissett DL, Robinson LR, Raleigh PS, Miyamoto K, Hakozaki T, et al. (2007) Reduction in the appearance of facial hyperpigmentation by topical N-acetyl glucosamine. J Cosmet Dermatol 6: 20-26.

31. Shatalebi MA, Mostafavi SA, Moghaddas A (2010) Niosome as a drug carrier for topical delivery of $\mathrm{N}$-acetyl glucosamine. Res Pharm Sci 5: 107-117.

32. Lee SH, Choi SY, Kim H, Hwang JS, Lee BG, et al. (2002) Mulberroside F isolated from the leaves of Morus alba inhibits melanin biosynthesis. Biol Pharm Bull 25: 1045-1048.

33. Arfan M, Khan R, Rybarczyk A, Amarowicz R (2012) Antioxidant activity of mulberry fruit extracts. Int J Mol Sci 13: 2472-2480.

34. Baumann L, Woolery-Lloyd H, Friedman A (2009) "Natural" ingredients in cosmetic dermatology. J Drugs Dermatol 8: s5-9.

35. Zheng ZP, Tan HY, Wang M (2012) Tyrosinase inhibition constituents from the roots of Morus australis. Fitoterapia 83: 1008-1013.

36. Alvin G, Catambay N, Vergara A, Jamora MJ (2011) A comparative study of the safety and efficacy of $75 \%$ mulberry (Morus alba) extract oil versus 
placebo as a topical treatment for melasma: a randomized, single-blind, placebo-controlled trial. J Drugs Dermatol 10: 1025-1031.

37. Altaei $\mathrm{T}$ (2012) The treatment of melasma by silymarin cream. BMC Dermatol 12: 18.

38. Galgut JM1, Ali SA (2011) Effect and mechanism of action of resveratrol: a novel melanolytic compound from the peanut skin of Arachis hypogaea. J Recept Signal Transduct Res 31: 374-380.

39. Fisk WA, Agbai O2, Lev-Tov HA3, Sivamani RK4 (2014) The use of botanically derived agents for hyperpigmentation: a systematic review. J Am Acad Dermatol 70: 352-365.

40. Hakozaki T, Minwalla L, Zhuang J, Chhoa M, Matsubara A, et al. (2002) The effect of niacinamide on reducing cutaneous pigmentation and suppression of melanosome transfer. Br J Dermatol 147: 20-31.

41. Navarrete-Solís J, Castanedo-Cázares JP, Torres-Álvarez B, Oros-Ovalle C, Fuentes-Ahumada C, et al. (2011) A Double-Blind, Randomized Clinical Trial of Niacinamide $4 \%$ versus Hydroquinone $4 \%$ in the Treatment of Melasma. Dermatol Res Pract 2011: 379173.

42. Schurink M, van Berkel WJ, Wichers HJ, Boeriu CG (2007) Novel peptides with tyrosinase inhibitory activity. Peptides 28: 485-495.

43. Ishikawa M, Kawase I, Ishii F (2007) Combination of amino acids reduces pigmentation in B16F0 melanoma cells. Biol Pharm Bull 30: 677-681.

44. Abu Ubeid A, Zhao L, Wang Y, Hantash BM (2009) Short-sequence oligopeptides with inhibitory activity against mushroom and human tyrosinase. J Invest Dermatol 129: 2242-2249.

45. Ubeid AA, Do S, Nye C, Hantash BM (2012) Potent low toxicity inhibition of human melanogenesis by novel indole-containing octapeptides. Biochim Biophys Acta 1820: 1481-1489.

46. Hantash BM, Jimenez F (2009) A split-face, double-blind, randomized and placebo-controlled pilot evaluation of a novel oligopeptide for the treatment of recalcitrant melasma. J Drugs Dermatol 8: 732-735.

47. Hantash BM, Jimenez F (2012) Treatment of mild to moderate facial melasma with the Lumixyl topical brightening system. J Drugs Dermatol 11: 660-662.

48. Ramírez SP, Carvajal AC, Salazar JC, Arroyave G, Flórez AM, et al. (2013) Open-label evaluation of a novel skin brightening system containing $0.01 \%$ decapeptide- 12 in combination with $20 \%$ buffered glycolic acid for the treatment of mild to moderate facial melasma. J Drugs Dermatol 12: e106-110.

49. Farwick M, Maczkiewitz U, Lersch P, Summers B, Rawlings AV (2011) Facial skin-lightening benefits of the tetrapeptide Pro-Lys-Glu-Lys on subjects with skin types V-VI living in South Africa. J Cosmet Dermatol 10: 217-223.

50. Na JI, Choi SY, Yang SH, Choi HR, Kang HY, et al. (2013) Effect of tranexamic acid on melasma: a clinical trial with histological evaluation. J Eur Acad Dermatol Venereol 27: 1035-1039.

51. Lee JH, Park JG, Lim SH, Kim JY, Ahn KY, et al. (2006) Localized intradermal microinjection of tranexamic acid for treatment of melasma in Asian patients: a preliminary clinical trial. Dermatol Surg 32: 626-631.

52. Kanechorn Na Ayuthaya P, Niumphradit N, Manosroi A, Nakakes A (2012) Topical 5\% tranexamic acid for the treatment of melasma in Asians: a double-blind randomized controlled clinical trial. J Cosmet Laser Ther 14: 150-154.

53. Tse TW, Hui E (2013) Tranexamic acid: an important adjuvant in the treatment of melasma. J Cosmet Dermatol 12: 57-66.

54. Cho HH, Choi M, Cho S, Lee JH (2013) Role of oral tranexamic acid in melasma patients treated with IPL and low fluence QS Nd:YAG laser. J Dermatolog Treat 24: 292-296.

55. Lehraiki A, Abbe P1, Cerezo M1, Rouaud F1, Regazzetti C2, et al. (2014) Inhibition of melanogenesis by the antidiabetic metformin. J Invest Dermatol 134: 2589-2597.

56. Zakopoulou N, Kontochristopoulos G (2006) Superficial chemical peels. J Cosmet Dermatol 5: 246-253.

57. Grover C, Reddu BS (2003) The therapeutic value of glycolic acid peels in dermatology. Indian J Dermatol Venereol Leprol 69: 148-150.
58. Kumari R, Thappa DM (2010) Comparative study of trichloroacetic acid versus glycolic acid chemical peels in the treatment of melasma. Indian J Dermatol Venereol Leprol 76: 447.

59. Grimes PE (1999) The safety and efficacy of salicylic acid chemical peels in darker racial-ethnic groups. Dermatol Surg 25: 18-22.

60. Safoury OS, Zaki NM, El Nabarawy EA, Farag EA (2009) A study comparing chemical peeling using modified Jessner's solution and 15\% trichloroacetic Acid versus 15\% trichloroacetic acid in the treatment of melasma. Indian J Dermatol 54: 41-45.

61. Sarkar R, Bansal S, Garg VK (2012) Chemical peels for melasma in darkskinned patients. J Cutan Aesthet Surg 5: 247-253.

62. Deprez P (2003) Easy Phytic Solution: A New Alpha Hydroxy Acid Peel with Slow Release and without Neutralization. Int J Cosm Surg Aesth Derm 5: 45-51.

63. Ilknur T, BiÃ§ak MU, DemirtaÅŸoÄŸlu M, Ozkan S (2010) Glycolic acid peels versus amino fruit acid peels in the treatment of melasma. Dermatol Surg 36: 490-495.

64. Taylor CR, Anderson RR (1994) Ineffective treatment of refractory melasma and postinflammatory hyperpigmentation by Q-switched ruby laser. J Dermatol Surg Oncol 20: 592-597.

65. Nouri K, Bowes L, Chartier T, Romagosa R, Spencer J (1999) Combination treatment of melasma with pulsed $\mathrm{CO} 2$ laser followed by Q-switched alexandrite laser: a pilot study. Dermatol Surg 25: 494-497.

66. Angsuwarangsee S, Polnikorn N (2003) Combined ultrapulse CO2 laser and Q-switched alexandrite laser compared with Q-switched alexandrite laser alone for refractory melasma: split-face design. Dermatol Surg 29: 59-64.

67. Arora P, Sarkar R, Garg VK, Arya L (2012) Lasers for treatment of melasma and post-inflammatory hyperpigmentation. J Cutan Aesthet Surg 5: 93-103.

68. Berlin AL, Dudelzak J, Hussain M, Phelps R, Goldberg DJ (2008) Evaluation of clinical, microscopic, and ultrastructural changes after treatment with a novel Q-switched Nd:YAG laser. J Cosmet Laser Ther 10: 76-79.

69. Polnikorn $\mathrm{N}$ (2008) Treatment of refractory dermal melasma with the MedLite C6 Q-switched Nd:YAG laser: two case reports. J Cosmet Laser Ther 10: 167-173.

70. Wattanakrai P1, Mornchan R, Eimpunth S (2010) Low-fluence Qswitched neodymium-doped yttrium aluminum garnet $(1,064 \mathrm{~nm})$ laser for the treatment of facial melasma in Asians. Dermatol Surg 36: 76-87.

71. Sim JH, Park YL, Lee JS, Lee SY, Choi WB, et al. (2014) Treatment of melasma by low-fluence $1064 \mathrm{~nm}$ Q-switched Nd:YAG laser. J Dermatolog Treat 25: 212-217.

72. Jeong SY, Shin JB, Yeo UC, Kim WS, Kim IH (2010) Low-fluence Qswitched neodymium-doped yttrium aluminum garnet laser for melasma with pre- or post-treatment triple combination cream. Dermatol Surg 36: 909-918.

73. Kar HK, Gupta L, Chauhan A (2012) A comparative study on efficacy of high and low fluence Q-switched Nd:YAG laser and glycolic acid peel in melasma. Indian J Dermatol Venereol Leprol 78: 165-171.

74. Na SY, Cho S, Lee JH (2012) Intense Pulsed Light and Low-Fluence QSwitched Nd:YAG Laser Treatment in Melasma Patients. Ann Dermatol 24: 267-273.

75. Kauvar AN (2012) Successful treatment of melasma using a combination of microdermabrasion and Q-switched Nd:YAG lasers. Lasers Surg Med 44: 117-124.

76. Polnikorn N (2010) Treatment of refractory melasma with the MedLite C6 Q-switched Nd:YAG laser and alpha arbutin: a prospective study. J Cosmet Laser Ther 12: 126-131.

77. Chan NP, Ho SG, Shek SY, Yeung CK, Chan HH (2010) A case series of facial depigmentation associated with low fluence Q-switched 1,064 nm Nd:YAG laser for skin rejuvenation and melasma. Lasers Surg Med 42: 712-719.

78. Manaloto RM, Alster T (1999) Erbium:YAG laser resurfacing for refractory melasma. Dermatol Surg 25: 121-123. 
79. Trelles MA, Velez M, Gold MH (2010) The treatment of melasma with topical creams alone, $\mathrm{CO} 2$ fractional ablative resurfacing alone, or a combination of the two: a comparative study. J Drugs Dermatol 9: 315-322.

80. Katz TM, Glaich AS, Goldberg LH, Firoz BF, Dai T, et al. (2010) Treatment of melasma using fractional photothermolysis: a report of eight cases with long-term follow-up. Dermatol Surg 36: 1273-1280.

81. Barysch MJ, Rümmelein B, Kolm I, Karpova MB, Schönewolf N, et al. (2012) Split-face study of melasma patients treated with non-ablative fractionated photothermolysis (1540 nm). J Eur Acad Dermatol Venereol 26: 423-430.

82. Wind BS, Kroon MW, Meesters AA, Beek JF, van der Veen JP, et al. (2010) Non-ablative $1,550 \mathrm{~nm}$ fractional laser therapy versus triple topical therapy for the treatment of melasma: a randomized controlled split-face study. Lasers Surg Med 42: 607-612.

83. Tourlaki A, Galimberti MG, Pellacani G, Bencini PL (2014) Combination of fractional erbium-glass laser and topical therapy in melasma resistant to triple-combination cream. J Dermatolog Treat 25: 218-222.

84. Karsai S, Fischer T, Pohl L, Schmitt L, Buhck H, et al. (2012) Is nonablative 1550-nm fractional photothermolysis an effective modality to treat melasma? Results from a prospective controlled single-blinded trial in 51 patients. J Eur Acad Dermatol Venereol 26: 470-476.

85. Hong SP, Han SS, Choi SJ, Kim MS, Won CH, et al. (2012) Split-face comparative study of $1550 \mathrm{~nm}$ fractional photothermolysis and trichloroacetic acid 15\% chemical peeling for facial melasma in Asian skin. J Cosmet Laser Ther 14: 81-86.

86. Neeley MR, Pearce FB, Collawn SS (2010) Successful treatment of malar dermal melasma with a fractional ablative COâ,, laser in a patient with type V skin. J Cosmet Laser Ther 12: 258-260.

87. Wang CC, Hui CY, Sue YM, Wong WR, Hong HS (2004) Intense pulsed light for the treatment of refractory melasma in Asian persons. Dermatol Surg 30: 1196-1200.

88. Li YH, Chen JZ, Wei HC, Wu Y, Liu M, et al. (2008) Efficacy and safety of intense pulsed light in treatment of melasma in Chinese patients. Dermatol Surg 34: 693-700.

89. Figueiredo Souza L, Trancoso Souza S (2012) Single-session intense pulsed light combined with stable fixed-dose triple combination topical therapy for the treatment of refractory melasma. Dermatol Ther 25: 477-480.

90. Polder KD, Bruce S (2012) Treatment of melasma using a novel 1,927$\mathrm{nm}$ fractional thulium fiber laser: a pilot study. Dermatol Surg 38: 199-206.

91. Niwa Massaki AB, Eimpunth S, Fabi SG, Guiha I, Groff W, et al. (2013) Treatment of melasma with the 1,927-nm fractional thulium fiber laser: a retrospective analysis of 20 cases with long-term follow-up. Lasers Surg Med 45: 95-101.

92. Ho SG, Yeung CK, Chan NP, Shek SY, Chan HH (2013) A retrospective study of the management of Chinese melasma patients using a $1927 \mathrm{~nm}$ fractional thulium fiber laser. J Cosmet Laser Ther 15: 200-206.

93. Jang WS, Lee CK, Kim BJ, Kim MN (2011) Efficacy of 694-nm Qswitched ruby fractional laser treatment of melasma in female Korean patients. Dermatol Surg 37: 1133-1140.

94. Hilton S, Heise H, Buhren BA, Schrumpf H, Bölke E, et al. (2013) Treatment of melasma in Caucasian patients using a novel 694-nm Qswitched ruby fractional laser. Eur J Med Res 18: 43.

95. Kim EJ, Park HY, Yaar M, Gilchrest BA (2005) Modulation of vascular endothelial growth factor receptors in melanocytes. Exp Dermatol 14: 625-633.

96. Kim EH, Kim YC, Lee ES, Kang HY (2007) The vascular characteristics of melasma. J Dermatol Sci 46: 111-116.

97. Plonka PM, Passeron T, Brenner M, Tobin DJ, Shibahara S, et al. (2009) What are melanocytes really doing all day long...? Exp Dermatol 18: 799-819.

98. Kang HY, Ortonne JP (2010) What should be considered in treatment of melasma. Ann Dermatol 22: 373-378.

99. Passeron T, Fontas E, Kang HY, Bahadoran P, Lacour JP, et al. (2011) Melasma treatment with pulsed-dye laser and triple combination cream: a prospective, randomized, single-blind, split-face study. Arch Dermatol 147: 1106-1108.

100. Arellano I, Cestari T, Ocampo-Candiani J, Azulay-Abulafia L, Neto PBT, et al. (2012) Preventing melasma recurrence: prescribing a maintenance regimen with an effective triple combination cream based on longstanding clinical severity. J Eur Acad Dermatol Venereol 26: 611-618. 